\title{
Publisher Correction to: Journal of Clinical Movement Disorders, volume 6
}

\author{
Journal of Clinical Movement Disorders
}

\section{Publisher Correction to: J Clin Mov Disord (2019) 6 https://doi.org/10.1186/$$
\text { s40734-019-0077-y }
$$

An error occurred during the publication of an article in Journal of Clinical Movement Disorders. This article was published in volume 6 with a duplicate citation number.

In this correction article the old and new citation metadata are published in Table 1.

The original article has been updated. The publisher apologizes for the inconvenience caused to our authors and readers.

\begin{tabular}{lcc} 
Table 1 & $\begin{array}{l}\text { Incorrect } \\
\text { citation } \\
\text { number }\end{array}$ & $\begin{array}{l}\text { Correct } \\
\text { citation } \\
\text { number }\end{array}$ \\
\hline $10.1186 /$ s40734-019-0077-y & 1 & 2
\end{tabular}

Published online: 07 August 2019

* Correspondence: info@biomedcentral.com

London, UK

Ready to submit your research? Choose BMC and benefit from:

- fast, convenient online submission

- thorough peer review by experienced researchers in your field

- rapid publication on acceptance

- support for research data, including large and complex data types

- gold Open Access which fosters wider collaboration and increased citations

- maximum visibility for your research: over 100M website views per year

At BMC, research is always in progress.

Learn more biomedcentral.com/submissions 